\title{
UPAYA MENINGKATKAN KEPATUHAN WAJIB PAJAK DI INDONESIA
}

\author{
Setiadi Alim Lim \\ Program Studi Akuntansi Politeknik Ubaya \\ Jalan Ngagel Jaya Selatan 169, Surabaya \\ Lilik Indrawati \\ Program Studi Manajemen \\ Fakultas Ekonomi Universitas Katolik Darma Cendika \\ Jalan Dr. Ir. H. Soekarno 201, Surabaya
}

\begin{abstract}
The success of a country in developing its country depends largely on the success of providing sufficient budget for the financing of development programs. The main sources of development financing budgets generally come from tax revenues. A country will be able to generate maximum revenue in the tax sector, if the country's tax compliance level is high. The results of research from Belkaoui (2004) showed that Indonesia was ranked 22nd out of 30 countries under study of tax compliance, with a tax compliance index of 2.53. This shows that the level of tax compliance in Indonesia is still low. Therefore, Indonesia must make various efforts to improve taxpayer compliance. The efforts undertaken must consider the factors that affect tax compliance.
\end{abstract}

\begin{abstract}
ABSTRAK
Keberhasilan suatu negara dalam membangun negaranya banyak tergantung pada keberhasilan untuk menyediakan anggaran yang cukup untuk pembiayaan program-program pembangunan. Sumber utama anggaran pembiayaan pembangunan umumnya berasal dari penerimaan di sektor pajak. Suatu negara akan mampu menghasilkan penerimaan yang maksimum di sektor pajak, apabila tingkat kepatuhan pajak di negara tersebut tinggi. Hasil penelitian dari Belkaoui (2004) menunjukkan Indonesia berada di urutan ke-22 dari 30 negara yang diteliti tingkat kepatuhan pajaknya, dengan indeks kepatuhan pajak sebesar 2,53. Hal ini menunjukkan bahwa tingkat kepatuhan pajak di Indonesia masih rendah. Oleh karena itu, Indonesia harus melakukan berbagai usaha untuk meningkatkan kepatuhan wajib pajaknya. Usaha-usaha yang dilakukan tersebut harus mempertimbangkan faktor-faktor yang mempengaruhi kepatuhan pajak.
\end{abstract}

Keywords: tax compliance, economic factors, institutional factors, taxpayer factors, social factors. 


\section{PENDAHULUAN}

Penerimaan dari setiap negara di dunia umumnya bisa dikategorikan menjadi penerimaan dari sumber pajak dan penerimaan dari sumber selain pajak. Bagi negara yang memiliki sumber daya alam melimpah, penerimaan negara yang utama bisa berasal dari pengelolaan sumber daya alam tersebut dan penerimaan dari sumber pajak hanya merupakan penerimaan negara yang bukan prioritas. Namun secara umum, hampir semua negara di dunia pendapatan utamanya berasal dari penerimaan di sektor pajak. Karena itu peranan dari penerimaan pajak untuk pembiayaan pengeluaran pemerintah dari tahun ke tahun terus meningkat.

Penerimaan pemerintah, baik yang bersumber dari pajak maupun dari luar pajak, akan digunakan untuk pembiayaan pengeluaran publik dalam rangka menghasilkan barang dan jasa publik yang akan dikonsumsi oleh masyarakat. Marandu et al. (2015) menyatakan banyak negara-negara berkembang sekarang memfokuskan kembali pada penerimaan dari sumber pajak untuk mengurangi ketergantungan berlebihan pada bantuan atau satu sumber pendapatan tertentu untuk pembangunan. Menurut Balliet and Lange (2013) dalam Gangl et al. (2015) membiayai barang publik melalui pajak merepresentasikan suatu dilema sosial, di mana kepentingan jangka pendek individu untuk meminimalkan membayar pajak adalah bertentangan dengan kepentingan kolektif jangka panjang untuk memastikan pembayaran pajak yang cukup untuk membiayai barang-barang publik.

Ada kecenderungan wajib pajak untuk meminimalkan jumlah pajak yang dibayar kepada negara. Pada da- sarnya usaha-usaha yang dilakukan wajib pajak untuk mengurangi jumlah pajak yang dibayar dapat dibedakan menjadi 2, yaitu tax avoidance dan tax evasion. Tax avoidance dapat diartikan sebagai usaha-usaha yang dilakukan oleh wajib pajak untuk meminimalkan jumlah pajak yang dibayar dengan menggunakan cara-cara yang tidak bertentangan dengan peraturan perpajakan yang berlaku. Sedangkan tax evasion dapat didefinisikan sebagai usaha-usaha yang dilakukan oleh wajib pajak untuk meminimalkan jumlah pajak yang dibayar dengan menggunakan cara-cara yang bertentangan dengan peraturan perpajakan yang berlaku.

Menurut Chau and Leung (2009) tax evasion adalah fenomena yang berlaku secara universal yang berada di semua lapisan masyarakat dan sistem ekonomi termasuk di negara-negara maju maupun berkembang. Tindakan tax evasion yang dilakukan wajib pajak menimbulkan kerugian besar dalam penerimaan pajak dari suatu negara. Andreoni et al. (1998) menyatakan untuk periode tahun pajak 1973 sampai dengan 1992 terjadi tax gap dengan nilai nominal meningkat hampir lima kali lipat, dari US\$ 22,7 milyar menjadi US\$ 95,3 milyar. Baru-baru ini ditaksir bahwa dalam 5 tahun yang akan datang kerugian yang disebabkan tax evasion kurang lebih US\$ 21 milyar di Amerika Serikat (Adams, 2013 dalam Fukofuka, 2013), US\$ 30 milyar per-tahun di Rusia (Amos, 2013 dalam Fukofuka, 2013), US\$ 21 milyar per-tahun di United Kingdom (Wright, 2013 dalam Fukofuka, 2013) dan US\$ 30 milyar per-tahun di Yunani (Daley, 2010 dalam Fukofuka, 2013). Namun Jimenez and Iyer (2016) menyatakan 
kerugian yang lebih besar, di mana baru-baru ini estimasi Internal Revenue Service (IRS) menunjukkan kurang lebih US\$ 385 milyar kerugian dari pendapatan pajak di tahun 2006 yang terjadi karena adanya kegiatan tax evasion.

Tax Justice Network (2011) dalam Marandu et al. (2015) menyebutkan kerugian pendapatan pajak karena tax evasion di seluruh dunia diestimasi di atas US\$ 3,1 triliun atau sekitar 5,1\% dari Pendapatan Domestik Bruto (PDB) dunia. Ini berarti sekitar 54,9\% belanja kesehatan hilang karena tax evasion. Dampak tidak membayar pajak secara sengaja kepada pemerintah lebih parah di negaranegara berkembang. Sebagai contoh, $97,7 \%$ dan $138,5 \%$ dari anggaran untuk kesehatan di negara-negara Afrika dan Amerika Selatan hilang karena tax evasion.

Menghadapi situasi yang demikian langkah-langkah penegakan hukum yang keras perlu dilakukan, khususnya bagi wajib pajak yang dengan sengaja tidak membayar pajak yang menjadi kewajibannya. Namun biasanya tindakan penegakan hukum yang dilakukan memerlukan biaya yang cukup besar dan waktu yang cukup panjang. Untuk melakukan tindakan pemeriksaan pajak secara besar-besaran terhadap wajib pajak diperlukan sumber daya tenaga pemeriksa yang banyak dan ini jelas memerlukan biaya yang sangat besar. Kemudian apabila dari hasil pemeriksaan ditemukan wajib pajak kurang membayar pajak dalam jumlah yang sangat besar, maka otoritas pajak dapat menerbitkan surat penagihan pajak, tetapi tidak bisa seketika memaksa wajib pajak tersebut untuk membayar pajak yang kurang dibayar saat itu juga. Karena wajib pajak biasanya mempunyai hak untuk melakukan upaya hukum lainnya seperti keberatan, banding dan proses hukum lainnya yang memakan waktu yang panjang. Akibatnya hasil pemeriksaan yang menghasilkan kurang bayar tersebut baru dapat diterima dananya setelah sekian lama.

Dari uraian di atas, nampak bahwa tindakan penegakan hukum saja tidak cukup untuk meminimalkan tax evasion dan meningkatkan penerimaan pajak. Tindakan penegakan hukum yang merupakan usaha bersifat represif, harus dibarengi dengan usaha yang bersifat preventif (pencegahan). Otoritas pajak dapat melakukan usaha-usaha untuk mendorong wajib pajak agar patuh untuk membayar pajak yang menjadi kewajibannya. Kepatuhan pajak yang dimaksud di sini adalah kepatuhan pajak dengan suka rela (voluntary tax compliance), artinya wajib pajak dapat patuh untuk memenuhi kewajiban perpajakannya tanpa harus melalui tindakan hukum yang bersifat represif.

Agar usaha-usaha untuk mendorong wajib pajak tidak melakukan tax evasion dan patuh untuk membayar pajak yang menjadi kewajibannya secara suka rela (voluntary tax compliance), maka perlu dipahami faktor-faktor yang mendorong wajib pajak untuk menjadi patuh dan menjadi tidak patuh. Bagi Indonesia yang menerapkan sistem self assessment dalam sistem pemungutan pajaknya, masalah kepatuhan pajak ini menjadi faktor sangat penting dalam menentukan keberhasilan memenuhi target penerimaan pajak. Tulisan ini akan mencoba menguraikan faktor-faktor tersebut berdasarkan beberapa tulisan dari para ahli sebelumnya dan memberikan 
langkah-langkah rekomendasi yang mungkin bermanfaat bagi para pengambil keputusan di Indonesia guna meningkatkan kepatuhan wajib pajak dalam rangka memaksimalkan penerimaan negara dari sektor pajak.

\section{PENGERTIAN KEPATUHAN PAJAK}

Ada banyak pengertian dari kepatuhan pajak (tax compliance). Andreoni et al. (1998) dalam Palil (2010) menyatakan kepatuhan pajak dapat didefinisikan sebagai kesediaan dari wajib pajak guna mematuhi hukum pajak agar memperoleh keseimbangan dalam perekonomian negara. James and Alley (2002) memberikan definisi final mengenai kepatuhan pajak sebagai kesediaan individu dan entitas kena pajak lainnya untuk bertindak sesuai dengan semangat dan hukum pajak yang tertulis serta prosedur administrasi perpajakan tanpa perlu adanya penerapan kegiatan penegakan hukum.

Song and Yarbrough (1978) dalam Palil and Mustapha (2011) menyatakan kepatuhan pajak adalah kemampuan dan kesediaan wajib pajak untuk mematuhi hukum pajak yang ditentukan oleh etika, lingkungan hukum dan faktor situasional lainnya pada waktu dan tempat tertentu. Kirchler (2007) dalam Jayawardane (2015) memberikan definisi yang lebih sederhana mengenai kepatuhan pajak yaitu kesediaan wajib pajak untuk membayar pajak mereka. Alm (1991) dan Jackson and Milliron (1986) dalam Palil (2010) mendefinisikan kepatuhan pajak sebagai pelaporan semua penghasilan dan pembayaran semua pajak dengan cara memenuhi ketentuan hukum, peraturan pajak dan keputusan pengadilan. Kepatuhan pa- jak juga didefinisikan oleh beberapa otoritas pajak sebagai kemampuan dan kesediaan wajib pajak untuk patuh terhadap hukum pajak, mendeklarasikan penghasilan yang benar setiap tahun dan membayar jumlah pajak yang benar secara tepat waktu (Internal Revenue Service (IRS), 2009; Australia Tax Office (ATO), 2009; Inland Revenue Board of Malaysia (IRB), 2009 dalam Palil and Mustapha, 2011). Menurut Palil (2010) berdasarkan definisi dari beberapa penulis sebelumnya ada beberapa kata kunci digunakan untuk mendefinisikan kepatuhan pajak, yaitu: kepatuhan, kemampuan dan kerelaan (McBarnet, 2001; Andreoni et al., 1998; Kirchler, 2007).

Dari beberapa definisi di atas, kepatuhan pajak dapat diartikan sebagai kesediaan wajib pajak dengan suka rela (voluntary) untuk mematuhi Undang-Undang Perpajakan dan peraturan pelaksana pajak lainnya, mendeklarasikan semua penghasilan, beban, aset dan kewajibannya secara benar dan membayar serta melaporkan semua kewajiban pajaknya secara benar dan tepat waktu.

McBarnet (2001) membagi tingkat kepatuhan pajak dari wajib pajak menjadi beberapa tingkatan, yaitu: (1) comitted compliance taxpayer adalah wajib pajak yang bersedia membayar semua kewajiban pajaknya dengan suka rela; (2) capitulative compliance taxpayer adalah wajib pajak yang membayar kewajiban pajaknya dengan enggan, mengeluh tetapi tetap membayar kewajiban pajaknya; (3) non compliance taxpayer adalah wajib pajak yang tidak patuh dalam membayar kewajiban pajaknya; (4) creative compliance taxpayer adalah wajib pajak yang akan berusaha 
mengurangi kewajibannya untuk membayar pajak dengan cara memanfaatkan kelemahan yang ada dalam Undang-Undang pajak. Dalam praktik nyata non compliance taxpayer adalah wajib pajak yang melakukan praktik creative compliance taxpayer adalah wajib pajak yang melakukan tax avoidance.

\section{FAKTOR-FAKTOR YANG MEMPENGARUHI KEPATUHAN PAJAK}

Hyun (2005) menyatakan teori mengenai kepatuhan pajak dipelopori oleh Allingham and Sandmo (1972) dalam kerangka kerja teori game, di mana tax evasion diperlakukan sebagai suatu aset yang beresiko, yang biasanya ditetapkan oleh pemeriksaan pajak dan tingkat hukuman. Model yang dikembangkan oleh Allingham and Sandmo (1972) ini menjelaskan bahwa wajib pajak dalam bersikap patuh atau tidak patuh terhadap kewajiban perpajakannya akan mempertimbangkan antara manfaat yang didapat dengan bersikap patuh dan resiko/ beban yang akan ditanggung bila bersikap tidak patuh terutama, resiko hukuman jika ditemukan kecurangan dalam proses pemeriksaan pajak.

Allingham and Sandmo (1972) mengasumsikan bahwa perilaku pembayar pajak adalah rasional sesuai dengan aksioma Von NeumannMorgenstern untuk perilaku di bawah ketidakpastian yang akan mencoba memaksimalkan kegunaan dari penghasilannya yang dapat dikenakan pajak. Menurut Kirchler et al. (2007) keputusan untuk patuh berdasarkan pendekatan ekonomi neo klasik dari Allingham and Sandmo (1972) tergantung pada: (i) tingkat penghasilan yang aktual; (ii) tarif pajak; (iii) ke- mungkinan untuk diperiksa oleh otoritas pajak; (iv) besarnya sanksi/hukuman/denda. Menurut Hyun (2005) pendekatan teori game tidak dapat menjelaskan secara lengkap mengenai perilaku kepatuhan pajak. Banyak studi yang menjelaskan perilaku kepatuhan pajak dengan situasi yang lebih realistik dengan fokus pada determinan dari kepatuhan pajak dengan faktor-faktor ekonomi dan non ekonomi.

Devos (2014: 13) menyatakan pendekatan teorikal mengenai kepatuhan pajak biasanya dibagi menjadi pendekatan economic deterrence dan pendekatan perilaku yang luas termasuk pendekatan sosial dan psikologi keuangan. Faktor-faktor yang berhubungan dengan pendekatan economic deterrence: (1) kompleksitas dari sistem pajak; (2) tingkat layanan informasi penghasilan; (3) witholding dan pelaporan informasi; (4) tanggungjawab dan hukuman bagi yang menyiapkan; (5) kemungkinan untuk diperiksa; (6) tarif pajak aktual dan progresif; (7) hukuman untuk ketidakpatuhan. Model sosial dan psikologi keuangan fokus pada variabel: nilai moral, persepsi mengenai keadilan dari sistem pajak dan otoritas pajak. Jayawardane (2015) membahas faktor-faktor psikologikal: norma sosial, keadilan dan kesamaan, moral pajak dan persepsi mengenai pertanggungjawaban pemerintah/politikal.

James and Alley (2002) menunjukkan ada 2 pendekatan berkaitan dengan kepatuhan pajak, yaitu: pendekatan ekonomi dan pendekatan perilaku. Pendekatan ekonomi dikenal lebih sempit dan pendekatan perilaku dikenal lebih luas. Wajib pajak pada pendekatan ekonomi dikenal sebagai kalkulator egois yang hanya mempertimbangkan keuntungan dan kerugian 
finansial, sedangkan pada pendekatan perilaku dikenal sebagai warga negara yang baik.

Chau and Leung (2009) menyatakan 14 faktor kunci yang dipelajari oleh para peneliti kepatuhan pajak seperti yang disampaikan Jackson and Milliron (1986) kemudian oleh Fischer et al. (1992) dibagi menjadi 4 kelompok yang dikenal sebagai Model Fischer. Faktor-faktor ini merupakan faktor-faktor kunci yang mempengaruhi kepatuhan pajak dari wajib pajak. Menurut Model Fischer faktor-faktor kunci tersebut adalah: (i) demografi (misalnya: usia, jenis kelamin dan pendidikan); (ii) kesempatan untuk menjadi tidak patuh (misalnya: tingkat penghasilan, sumber penghasilan dan pekerjaan); (iii) sikap dan persepsi (misalnya: keadilan dari sistem perpajakan dan pengaruh teman/rekan); (iv) sistem atau struktur pajak (misal: kompleksitas dari sistem pajak).

Palil (2010) mengelompokkan faktor-faktor yang mempengaruhi kepatuhan pajak menjadi 5 kelompok, yaitu: (1) faktor ekonomi yang terdiri dari: tarif pajak, pemeriksaan pajak, persepsi mengenai pengeluaran pemerintah; (2) faktor institusional yang terdiri dari: peranan (efisiensi) pemerintah/otoritas pajak, kesederhanaan dari administrasi dan Surat Pemberitahuan (SPT), kemungkinan untuk terdeteksi; (3) faktor sosial yang terdiri dari: etika dan sikap terhadap kepatuhan pajak, persepsi mengenai kesamaan dan keadilan, perubahan terhadap kebijakan pemerintah saat ini, referensi dari kelompok (keluarga dan teman); (4) faktor individu yang terdiri dari: batasan keuangan personal, kesadaran akan pelanggaran dan hukuman; (5) faktor lain yang terdiri dari: usia, tingkat penghasilan, budaya, pendidikan, jenis kelamin.

Kirchler et al. (2007) menyatakan suatu keputusan untuk patuh terhadap pajak tergantung pada: (1) tingkat penghasilan aktual; (2) tarif pajak; (3) kemungkinan diperiksa; dan (4) besarnya denda. Mișu (2011) membedakan faktor-faktor yang mempengaruhi wajib pajak untuk patuh atau tidak patuh menjadi faktor-faktor ekonomi dan faktor-faktor non ekonomi seperti Gambar 1 di bawah ini.

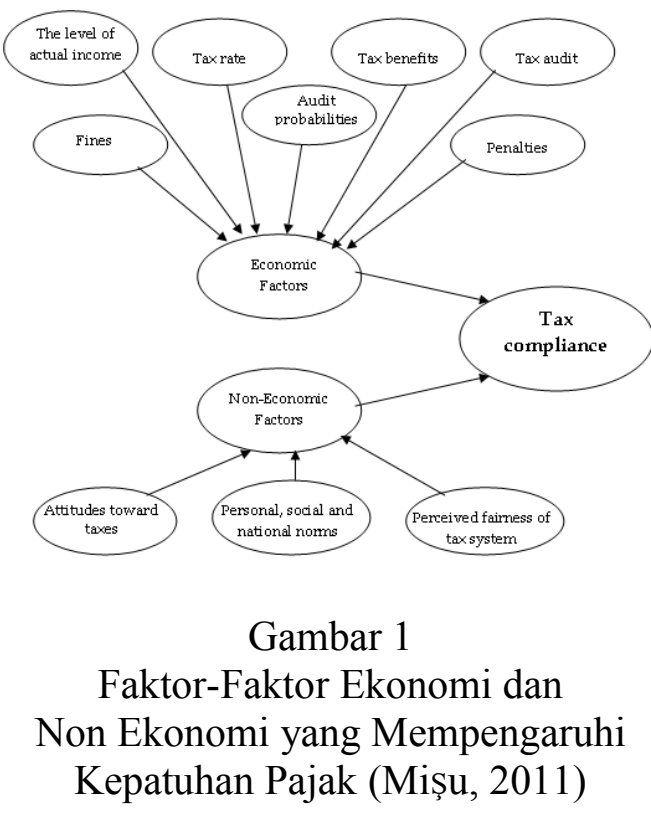

Berdasarkan uraian-uraian di atas, maka faktor-faktor yang menentukan kepatuhan wajib pajak akan dikelompokkan kembali menjadi: (i) faktor-faktor ekonomi; (ii) faktor-faktor yang berhubungan dengan pengambil kebijakan (otoritas); (iii) faktorfaktor yang berhubungan dengan wajib pajak; dan (iv) faktor-faktor sosial. Faktor-faktor ekonomi adalah faktorfaktor yang mempengaruhi kepatuhan wajib pajak yang dipengaruhi pertimbangan ekonomi. Wajib pajak cenderung akan mempertimbangkan kepatuhan membayar pajak dengan meng- 
gunakan analisis antara cost and benefit.

Faktor-faktor ekonomi terdiri dari: tarif pajak (tax rate), pemeriksaan pajak (tax audit), tingkat penghasilan aktual (level of actual income), sumber penghasilan (income source), denda (fine), hukuman (penalty), kemungkinan untuk diperiksa (audit probabilities) dan manfaat pajak (tax benefits). Faktor-faktor yang berhubungan dengan pengambil kebijakan adalah faktor-faktor yang berkaitan dengan kebijakan yang diambil oleh pemerintah (eksekutif) yang didukung oleh legislatif dan yudikatif. Faktorfaktor yang berhubungan dengan ini antara lain: kompleksitas sistem perpajakan (complexity of the tax system), kesamaan dan keadilan (equity and fairness), persepsi mengenai pengeluaran pemerintah (perception of government spending) dan peranan dari otoritas pajak (the role of the tax authority). Faktor-faktor yang berhubungan dengan wajib pajak adalah faktor-faktor yang berkaitan dengan karakteristik atau profil wajib pajak antara lain: usia (age), jenis kelamin (gender), pendidikan (education), kendala/batasan keuangan (financial constraints) dan sikap/perilaku (attitudes). Faktor-faktor sosial adalah faktor-faktor sosial yang berpengaruh pada wajib pajak untuk menjadi patuh atau tidak patuh, antara lain: budaya (culture), pengaruh dari rekan atau kelompok (peer influence/referent groups) dan norma sosial. Faktor-faktor yang mempengaruhi kepatuhan pajak dan terdiri dari: faktor-faktor ekonomi, faktor-faktor yang berhubungan dengan pengambil keputusan, faktorfaktor yang berhubungan dengan wajib pajak dan faktor-faktor sosial nampak seperti bagan pada Gambar 2.

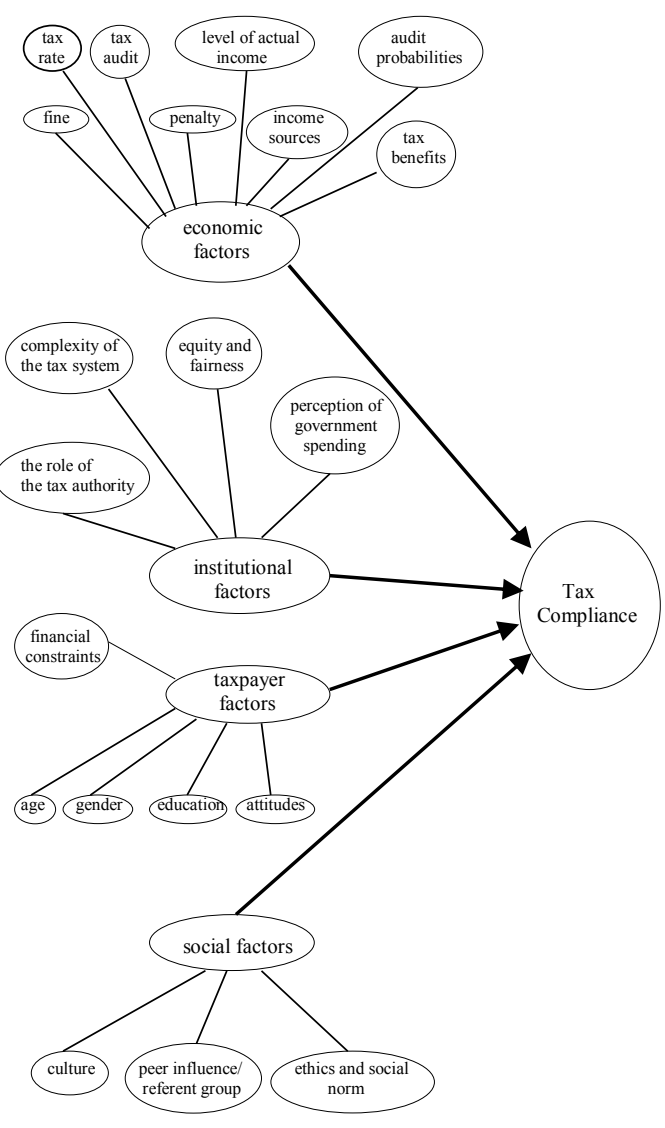

Gambar 2

Faktor-Faktor yang Mempengaruhi Kepatuhan Pajak

\section{TINGKAT KEPATUHAN WAJIB PAJAK DI INDONESIA}

Untuk mengukur tingkat kepatuhan dari wajib pajak tidaklah mudah, mengingat banyak faktor yang mempengaruhinya. Namun Belkaoui (2004) mencoba melakukan pengukuran tingkat kepatuhan pajak di beberapa negara dengan menggunakan variabel yang diberi nama indeks kepatuhan pajak. Indeks kepatuhan pajak ini diberi nilai minimum 0 dan nilai maksimum 6. Suatu negara yang memiliki indeks kepatuhan pajak sama dengan 0 , berarti semua wajib pajaknya tidak patuh membayar pajak. Sedangkan bila suatu negara mempunyai nilai indeks kepatuhan pajak sama 
dengan 6, berarti semua wajib pajaknya patuh membayar pajak. Indeks kepatuhan pajak dari 30 negara yang diteliti oleh Belkaoui (2004) tampak pada Tabel 1 (standar 0-6).

Tabel 1

Indeks Kepatuhan Pajak 30 Negara

\begin{tabular}{|c|c|c|}
\hline No. & Nama Negara & $\begin{array}{c}\text { Kepatuhan } \\
\text { Pajak }\end{array}$ \\
\hline 1. & Singapore & 5,05 \\
\hline 2. & New Zealand & 5,00 \\
\hline 3. & UK & 4,67 \\
\hline 4. & Australia & 4,58 \\
\hline 5. & Hongkong & 4,56 \\
\hline 6. & Switzerland & 4,49 \\
\hline 7. & USA & 4,47 \\
\hline 8. & Japan & 4,41 \\
\hline 9. & Malaysia & 4,34 \\
\hline 10. & Chile & 4,20 \\
\hline 11. & Norway & 3,96 \\
\hline 12. & France & 3,86 \\
\hline 13. & Canada & 3,77 \\
\hline 14. & Denmark & 3,70 \\
\hline 15. & Austria & 3,60 \\
\hline 16. & Finland & 3,53 \\
\hline 17. & Germany & 3,41 \\
\hline 18. & Thailand & 3,41 \\
\hline 19. & Netherlands & 3,40 \\
\hline 20. & Spain & 3,29 \\
\hline 21. & Taiwan & 3,25 \\
\hline 22. & Indonesia & 2,53 \\
\hline 23. & Mexico & 2,46 \\
\hline 24. & Argentina & 2,41 \\
\hline 25. & Poland & 2,19 \\
\hline 26. & Portugal & 2,18 \\
\hline 27. & Turkey & 2,07 \\
\hline 28. & Sweden & 1,91 \\
\hline 29. & Philippines & 1,83 \\
\hline 30. & Italy & 1,77 \\
\hline
\end{tabular}

Sumber: Belkaoui (2004)

Dari Tabel 1 di atas nampak bahwa tidak ada satu negara yang dapat mencapai angka maksimal dari indeks kepatuhan pajak, yaitu 6 . Singapore yang berada pada posisi teratas, angka indeks kepatuhan pajaknya hanya 5,05. Tabel tersebut juga menunjukkan bahwa tingkat kepatuhan pajak tidak berhubungan dengan tingkat kemajuan suatu negara. Tingkat kepatuhan pajak negara maju seperti Italia dan Swedia sangat rendah dengan indeks kepatuhan pajak kurang dari 2, dan lebih rendah dibandingkan dengan beberapa negara berkembang. Untuk negara di Asia: Singapore, Hongkong, Jepang dan Malaysia mempunyai tingkat kepatuhan pajak yang tinggi dengan indeks kepatuhan pajak lebih dari 4.

Indonesia dengan indeks kepatuhan pajak sebesar 2,53 berada di posisi ke-22 di antara 30 negara yang diteliti. Bila dibandingkan dengan 5 negara di Asia Tenggara yang diteliti, tingkat kepatuhan pajak Indonesia berada di posisi ke-4 di bawah Singapore, Malaysia dan Thailand, dan di atas Philippines.

\section{USAHA MENINGKATKAN KE- PATUHAN WAJIB PAJAK DI INDONESIA}

Bila dilihat dari indeks kepatuhan pajak menurut Belkaoui (2004) nampak bahwa tingkat kepatuhan pajak di Indonesia masih rendah. Oleh karena itu masih banyak ruang dan usaha yang dapat dilakukan untuk meningkatkan kepatuhan pajak di Indonesia.

Namun agar usaha-usaha yang dilakukan dapat mencapai sasaran yang diinginkan, maka usaha-usaha tersebut harus dilakukan dengan melihat faktor-faktor yang mempengaruhi kepatuhan pajak. Beberapa usaha yang dapat dilakukan dengan berpedoman pada faktor-faktor tersebut antara lain adalah:

1. Tarif Pajak (Tax Rate).

Whitte and Woodbury (1985), Ali et al. (2001) dan Torgler (2007) dalam Palil (2010) menyatakan 
menaikkan tarif marjinal pajak mungkin akan mendorong wajib pajak menghindari pajak. Tetapi menurunkan tarif pajak tidak selalu meningkatkan kepatuhan pajak (Trivedi et al., 2004; Kirchler, 2007 dalam Palil, 2010). Dari pernyataan tersebut nampak bahwa menaikkan tarif pajak akan menyebabkan kenaikan praktik tax evasion, yang berarti menurunkan tingkat kepatuhan pajak. Namun penurunan tarif pajak tidak pasti menghasilkan kenaikan tingkat kepatuhan pajak. Tetapi tarif pajak yang tinggi tentu akan menurunkan tingkat kepatuhan pajak. Oleh karenanya apabila tarif pajak dari suatu negara cukup tinggi, maka dapat dipertimbangkan untuk menurunkan tarif pajaknya. Tarif pajak yang dapat dijadikan acuan misalkan tarif pajak rata-rata seluruh negara di dunia atau tarif pajak negara-negara pada kawasan yang sama. Undang-Undang Pajak Penghasilan yang berlaku di Indonesia saat ini (Undang-Undang Nomor 7 Tahun 1983 tentang Pajak Penghasilan yang telah diubah beberapa kali, terakhir dengan Undang-Undang Nomor 36 tahun 2008) menetapkan tarif Pajak Penghasilan flat sebesar $25 \%$ untuk wajib pajak badan, dan tarif Pajak Penghasilan progresif sebesar 5\%,15\%, 25\% dan $30 \%$ untuk wajib pajak orang pribadi. Tabel 2 berikut ini menunjukkan tarif marjinal Pajak Penghasilan korporasi 20 negara dengan tarif marjinal Pajak Penghasilan korporasi tertinggi dan Tabel 3 menunjukkan tarif marjinal Pajak Penghasilan korporasi 20 negara dengan tarif marjinal Pajak Penghasilan korporasi terendah.
Tabel 2

Daftar 20 Negara dengan Tarif Marjinal Pajak Penghasilan Korporasi Tertinggi di Dunia

\begin{tabular}{|c|l|c|c|}
\hline No. & \multicolumn{1}{|c|}{ Nama Negara } & Tarif & Kawasan \\
\hline 1. & United Arab Emirates & $55 \%$ & Asia \\
\hline 2. & Puerto Rico & $39 \%$ & Amerika Utara \\
\hline 3. & United States & $38,9 \%$ & Amerika Utara \\
\hline 4. & Agentina & $35 \%$ & Amerika Selatan \\
\hline 5. & Chad & $35 \%$ & Afrika \\
\hline 6. & Congo, Democratic R. & $35 \%$ & Afrika \\
\hline 7. & Equatorial Guines & $35 \%$ & Afrika \\
\hline 8. & Guinea & $35 \%$ & Afrika \\
\hline 9. & Malta & $35 \%$ & Eropa \\
\hline 10. & Virgin Islands, U.S. & $35 \%$ & Amerika Utara \\
\hline 11. & Zambia & $35 \%$ & Afrika \\
\hline 12. & India & $34,6 \%$ & Asia \\
\hline 13. & Sint Maarten & $34,5 \%$ & Amerika Utara \\
\hline 14. & France & $34,4 \%$ & Eropa \\
\hline 15. & Brazil & $34 \%$ & Amerika Selatan \\
\hline 16. & Venezuela & $34 \%$ & Amerika Selatan \\
\hline 17. & Belgium & $34 \%$ & Eropa \\
\hline 18. & Monaco & $33,3 \%$ & Eropa \\
\hline 19. & Saint Lucia & $33,3 \%$ & Amerika Utara \\
\hline 20. & Cameroon & $33 \%$ & Afrika \\
\hline & Worldwide Average & $22,5 \%$ & N/A \\
\hline & Worldwide Weighted & $29,5 \%$ & N/A \\
\hline Average (by GDP) & & \\
\hline Sum & ber: Pomerleau and Poto & (2016) \\
\hline
\end{tabular}

Sumber: Pomerleau and Potosky (2016)

Tabel 3

Daftar 20 Negara dengan Tarif Marjinal Pajak Penghasilan Korporasi Terendah di Dunia

\begin{tabular}{|c|l|c|c|}
\hline No. & \multicolumn{1}{|c|}{ Nama Negara } & Tarif & Kawasan \\
\hline 1. & Albania & $15 \%$ & Eropa \\
\hline 2. & Georgia & $15 \%$ & Asia \\
\hline 3. & Cyprus & $12,5 \%$ & Eropa \\
\hline 4. & Ireland & $12,5 \%$ & Eropa \\
\hline 5. & Liechtenstein & $12,5 \%$ & Eropa \\
\hline 6. & Macao & $12 \%$ & Asia \\
\hline 7. & Moldova, Republic of & $12 \%$ & Eropa \\
\hline 8. & Oman & $12 \%$ & Asia \\
\hline 9. & Andorra & $10 \%$ & Eropa \\
\hline 10. & Bosnia and Herzegovina & $10 \%$ & Eropa \\
\hline 11. & Bulgaria & $10 \%$ & Eropa \\
\hline 12. & Gibraltar & $10 \%$ & Eropa \\
\hline 13. & Kyrgyzstan & $10 \%$ & Asia \\
\hline 14. & Macedonia, Former & $10 \%$ & Eropa \\
\hline 15. & Yugoslav Republic of & & \\
\hline 16. & Qaraguay & $10 \%$ & Amerika Selatan \\
\hline 17. & Timor-Leste & $10 \%$ & Asia \\
\hline 18. & Montenegro & $10 \%$ & Asia \\
\hline 19. & Turkmenistan & $9 \%$ & Eropa \\
\hline 20. & Uzbekistan & $8 \%$ & Asia \\
\hline & Worldwide Average & $7,5 \%$ & Asia \\
\hline & Worldwide Weighted & $29,5 \%$ & N/A \\
\hline & Average (by GDP) & & N/A \\
\hline Sum & ber: Pomerleau and & P & \\
\hline
\end{tabular}

Sumber: Pomerleau and Potosky (2016)

Dari Tabel 2 dapat dilihat bahwa negara yang memiliki tarif marjinal Pajak Penghasilan tertinggi berada di kawasan Afrika (6 negara), Amerika Utara (5 negara), Amerika Selatan (3 negara), Eropa 
(4 negara) dan Asia (2 negara). Pada Tabel 3 terlihat bahwa bahwa negara yang memiliki tarif marjinal Pajak Penghasilan terendah berada di kawasan Amerika Selatan (1 negara), Eropa (11 negara) dan Asia (8 negara). Sedangkan tarif Pajak Penghasilan negara-negara di kawasan Asia Tenggara dapat dilihat pada Tabel 4 berikut ini.

Tabel 4

Tarif Pajak Penghasilan (PPh.) Korporasi dan Orang Pribadi Beberapa Negara di Kawasan Asia Tenggara

\begin{tabular}{|c|l|c|c|c|}
\hline No. & Nama Negara & \multirow{2}{*}{$\begin{array}{l}\text { Tarif PPh. } \\
\text { Korporasi }\end{array}$} & \multicolumn{2}{|c|}{ Tarif PPh. Orang Pribadi } \\
\cline { 4 - 5 } & & $10 \%$ & Minimum & Maksimum \\
\hline 1. & Timor-Leste & $17 \%$ & $0 \%$ & N/A \\
\hline 2. & Singapore & $20 \%$ & $0 \%$ & $22 \%$ \\
\hline 3. & Brunei & $20 \%$ & $0 \%$ & $20 \%$ \\
\hline 4. & Cambodia & $20 \%$ & $0 \%$ & $35 \%$ \\
\hline 5. & Thailand & $20 \%$ & $5 \%$ & $35 \%$ \\
\hline 6. & Vietnam & $25 \%$ & $0 \%$ & $26 \%$ \\
\hline 7. & Malaysia & $25 \%$ & $5 \%$ & $30 \%$ \\
\hline 8. & Indonesia & $30 \%$ & $5 \%$ & $32 \%$ \\
\hline 9. & Philippines & $20,78 \%$ & $1,875 \%$ & $25 \%$ \\
\hline & Rata-rata & \multicolumn{3}{|l}{} \\
\hline
\end{tabular}

Dari Tabel 2 dan Tabel 3 nampak bahwa rata-rata tarif marjinal $\mathrm{Pa}$ jak Penghasilan korporasi negaranegara di seluruh dunia sebesar 22,5\%. Kemudian dari Tabel 4 terlihat rata-rata tarif Pajak Penghasilan untuk 9 negara di kawasan Asia Tenggara untuk wajib pajak badan (korporasi) sebesar 20,78\%, dan untuk wajib pajak orang pribadi minimum sebesar $1,875 \%$ dan maksimum sebesar $25 \%$. Berdasarkan data rata-rata tarif marjinal Pajak Penghasilan korporasi negara-negara di seluruh dunia dan rata-rata tarif Pajak Penghasilan untuk 9 negara di kawasan Asia Tenggara nampaknya tarif Pajak Penghasilan yang diterapkan di Indonesia masih terlalu tinggi. Oleh karena itu, maka usaha yang dapat dilakukan adalah menurun- kan tarif Pajak Penghasilan wajib pajak badan (korporasi) menjadi flat $20 \%$ dan wajib pajak orang pribadi progresif dengan hanya menggunakan 3 lapisan, yaitu: 5\%, $15 \%$ dan $25 \%$, masing-masing untuk lapisan penghasilan kena pajak Rp. 0,- sampai dengan $\mathrm{Rp}$. 250.000.000,-, kemudian di atas Rp. 250.000.000,- sampai dengan Rp. 500.000.000,- dan terakhir di atas Rp. 500.000.000,-. Perubahan mengenai lapisan penghasilan kena pajak ini juga dimaksudkan untuk penyesuaian dengan inflasi (ditetapkan tahun 2008 atau telah berlaku selama 9 tahun). Waktu yang tepat untuk melakukan perubahan ini adalah setelah tanggal 31 Maret 2017, yaitu setelah berakhirnya periode program pengampunan pajak.

2. Pemeriksaan Pajak dan Kemungkinan untuk Diperiksa (Tax Audit and Audit Probabilities).

Hubungan pemeriksaan pajak dengan tingkat kepatuhan pajak dari hasil-hasil penelitian sebelumnya menunjukkan hasil yang ambigu. Beberapa penelitian mengklaim bahwa pemeriksaan pajak mempunyai pengaruh yang positif pada tax evasion, sedangkan yang lain menunjukkan hubungan tersebut tidak signifikan (Palil, 2010). Namun demikian secara umum tetap dapat disimpulkan bahwa pemeriksaan pajak akan dapat mengubah perilaku wajib pajak untuk menjadi patuh dengan suka rela (voluntary compliance). Kebanyakan studi empirikal menemukan dukungan yang kuat untuk pengaruh dari kemungkinan diperiksa dengan kepatuhan pajak, walaupun pengaruhnya kadang-kadang dilaporkan 
lemah (Fischer et al., 1992 dalam Kirchler et al., 2007). Berdasarkan uraian tersebut, maka usaha yang dapat dilakukan adalah memperbanyak personil untuk melakukan tindakan pemeriksaan pajak, sehingga kemungkinan wajib pajak untuk diperiksa juga menjadi lebih tinggi. Namun hal tersebut harus ditetapkan secara hati-hati mengingat biaya yang dikeluarkan untuk melakukan pemeriksaan juga harus dipertimbangkan. Di samping itu setiap pemeriksa pajak harus dibekali dengan kemampuan pemeriksaan pajak yang memadai dan jangan ada sistem target terhadap pemeriksa pajak. Artinya pemeriksa pajak jangan dibebani target harus mendapatkan temuan pajak kurang bayar pada saat memeriksa wajib pajak. Hal ini secara psikologis akan mendorong pemeriksa pajak untuk melakukan tindakan pemeriksaan yang tidak profesional dan cenderung mencari-cari kesalahan wajib pajak, yang mana akan bermuara pada timbulnya perasaan antipati dari wajib pajak terhadap pemeriksa pajak. Akibatnya kepatuhan wajib pajak dengan suka rela (voluntary compliance) bukannya naik, tetapi malah akan menurun. Untuk wajib pajak yang terbukti telah patuh secara suka rela (voluntary compliance) kemungkinannya untuk diperiksa diperkecil, agar memotivasi wajib pajak yang lain untuk menjadi patuh dengan suka rela.

3. Denda dan Hukuman (Fine and Penalty).

Denda dan hukuman diharapkan dapat menjadi faktor pencegah wajib pajak untuk bersikap tidak patuh. Namun hasil-hasil peneliti- an yang ada mengenai hubungan besarnya denda dengan kepatuhan pajak saling kontrakdiksi. Ada hasil penelitian yang menyatakan bahwa besarnya denda mempunyai pengaruh terhadap kepatuhan pajak (Alm et al., 1992; Friedland et al., 1978; Park and Hyun, 2003 dalam Kirchler, 2007). Tetapi ada pula yang menyatakan tidak ada hubungan antara besarnya denda dengan tingkat kepatuhan pajak (Pommerehne et al., 1996; Ali et al., 2001; Webley et al., 1991 dalam Kirchler, 2007). Sedangkan mengenai hubungan hukuman dengan kepatuhan pajak Allingham and Sandmo (1972) dalam Chau and Leung (2009) menyatakan kepatuhan pajak dapat ditingkatkan melalui peningkatkan hukuman yang berhubungan dengan ketidakpatuhan. Hal senada juga ditunjukkan dari hasil penelitian Witte and Woobury (1985), Grasmick and Scott (1982), Hasseldine (2007) dalam Chau and Leung (2009). Mişu (2011) menyatakan tingkat hukuman untuk masing-masing subjek pajak dibedakan melalui perbedaan tingkat pelanggaran pajak yang dilakukan, seperti tidak menyampaikan SPT (Surat Pemberitahuan), menyampaikan SPT tetapi melaporkan penghasilan terlalu kecil dari yang sebenarnya, tidak ada pembukuan dari faktur, penerimaan uang dan seterusnya. Hyun (2005) menyatakan jika wajib pajak melakukan pelanggaran yang disengaja, hukumannya harus dibedakan dengan yang melakukannya secara tidak sengaja. Dalam Undang-Undang Nomor 6 Tahun 1983 tentang Ketentuan Umum dan Tata Cara Perpajakan 
yang telah diubah beberapa kali, terakhir dengan Undang-Undang Nomor 16 Tahun 2009 diatur mengenai sanksi dan hukuman terhadap wajib pajak yang tidak patuh. Masalah denda diatur cukup banyak, yaitu: pasal 7 ayat (1) dan (2), pasal 8 ayat (2), (2A), (3) dan (5), pasal 9 ayat $(2 \mathrm{~A})$ dan (2B), pasal 13 ayat (2) dan (3), pasal 13A, pasal 14 ayat (3), (4) dan (5), pasal 15 ayat $(2)$, pasal $17 \mathrm{C}$ ayat (5), pasal $17 \mathrm{D}$ ayat (5), pasal 19 ayat (1), (2) dan (3), pasal 20 ayat (1) dan (2), pasal 25 ayat (9) dan (10), pasal 36A ayat (1) dan (2). Masalah hukuman yang berhubungan dengan pidana diatur dalam: pasal 36A ayat (3) dan (4), pasal 38, 39, 39A, 41, 41A, 41B, 41C, 43, 43A, 44, 44A dan 44B. Di samping itu masalah denda juga diatur dengan Undang-Undang Nomor 19 Tahun 1997 tentang Penagihan Pajak dengan Surat Paksa yang telah diubah dengan UndangUndang Nomor 19 Tahun 2000. Secara umum denda dan hukuman yang tercantum dalam UndangUndang Perpajakan di Indonesia sudah cukup baik dan mencakup semua pelanggaran kewajiban perpajakan serta sudah dibedakan antara tindakan yang disengaja dan tidak disengaja (alpa). Hal yang harus diperbaiki mengenai pemeriksa pajak yang harus betul-betul kompeten dan memahami filosofi pemeriksaan pajak bukan untuk menghukum wajib pajak dengan pasal-pasal pidana, tetapi untuk pembinaan wajib pajak dan peningkatan penerimaan negara dari sektor pajak.

4. Tingkat Penghasilan Aktual (Level of Actual Income).
Penelitian yang ada memberikan hasil yang berbeda antara beberapa penelitian dengan beberapa penelitian yang lain mengenai hubungan antara tingkat penghasilan aktual dengan tingkat kepatuhan pajak. Hal ini seperti yang diungkapkan oleh Kirchler et al. (2007) bahwa meskipun sebagian besar penelitian melaporkan hubungan negatif antara pendapatan dan kepatuhan, namun ada juga yang menunjukkan hubungan positif bahkan tidak ada hubungan. Sebagian besar penelitian menunjukkan bahwa wajib pajak dengan tingkat penghasilan yang tinggi mempunyai tingkat kepatuhan yang lebih rendah (Slemrod, 1985; Hannemann and Pommerehne, 1989; Ali et al., 2001 dalam Kirchler, 2007). Karena adanya hubungan yang negatif ini, maka usaha yang dilakukan adalah memberikan prioritas pengawasan yang lebih ketat terhadap wajib pajak dengan tingkat penghasilan tinggi dalam melaksanakan kewajiban perpajakannya, termasuk tindakan pemeriksaan.

5. Sumber Penghasilan (Income Sources).

Chau and Leung (2009) menyatakan umumnya kesempatan lebih besar untuk menjadi tidak patuh ada pada wajib pajak yang bekerja sendiri dan penghasilannya bukan merupakan objek dari witholding tax. Survei yang dilakukan oleh Aitken and Bonneville (1980) dan Groenland and Voldhoven (1983) dalam Chau and Leung (2009) menemukan bahwa wajib pajak yang bekerja sendiri lebih mungkin melakukan berbagai bentuk ketidakpatuhan pajak. Berkaitan dengan hal ini, maka usaha yang dilakukan 
adalah melakukan pengawasan yang lebih ketat kepada wajib pajak yang memperoleh penghasilan dari bekerja sendiri dalam melaksanakan kewajiban perpajakannya dan mempeluas penghasilan yang menjadi objek pemotongan/pemungutan witholding tax.

6. Manfaat Pajak (Tax Benefits). Yang dimaksud manfaat pajak di sini adalah adanya keringanan atau insentif pajak untuk wajib pajak dengan bentuk entitas tertentu. Misalkan bila ada insentif pajak yang yang besar untuk wajib pajak orang pribadi, maka ada kemungkinan wajib pajak yang melaksanakan kegiatan usahanya melalui bentuk usaha badan akan berpindah melakukan kegiatan usahanya melalui wajib pajak orang pribadi atau menggeser penghasilannya dari badan ke orang pribadi. Demikian pula apabila ada perbedaan perlakuan perpajakan antara satu bentuk badan dengan bentuk badan lainnya akan terjadi hal yang demikian pula. Dalam Undang-Undang Perpajakan di Indonesia ada beberapa insentif atau keringanan pajak. Usaha yang dilakukan adalah meminimalkan perlakuan pajak yang berbeda atau pemberian insentif/keringanan pajak antara wajib pajak yang satu dengan wajib pajak yang lain.

7. Kompleksitas Sistem Perpajakan (Complexity of The Tax System). Clotfelter (1983), Milliron (1985) dan Richardson (2006) dalam Chau and Leung (2009) menyatakan hal yang senada bahwa sistem pajak yang kompleks berhubungan dengan pelaporan pajak yang lebih rendah, keputusan menjadi tidak patuh dan perilaku tax evasion.
Peraturan perpajakan di Indonesia saat ini juga kompleks, seperti banyaknya/bervariasinya tarif Pajak Penghasilan yang bersifat final yang kadang-kadang sangat menyulitkan wajib pajak untuk memahaminya. Di samping itu pemungutan Pajak Pertambahan Nilai oleh bendaharawan pemerintah dan badan-badan tertentu merupakan barrier bagi mekanisme pengkreditan Pajak Pertambahan Nilai Masukan dengan Pajak Pertambahan Nilai Keluaran yang akhirnya bermuara pada Pajak Pertambahan Nilai Lebih Bayar. Berarti menambah pekerjaan administrasi pengajuan dan penanganan restitusi bagi pengusaha kena pajak dan otoritas pajak. Berkaitan dengan hal ini, maka usaha yang dapat dilakukan adalah menyederhanakan tarif pemotongan Pajak Penghasilan bersifat final yang sedemikian banyaknya dan menghilangkan kewajiban memungut Pajak Pertambahan Nilai bagi bendaharawan pemerintah dan badanbadan tertentu.

8. Kesamaan dan Keadilan (Equity and Fairness).

Survei yang dilakukan oleh Scott and Grasmick (1982) dan Spicer and Lundstedt (1976) dalam Chau and Leung (2009) menunjukkan bahwa responden percaya bahwa sistem pajak yang tidak adil lebih mungkin membuat perilaku ketidakpatuhan pajak. Chau and Leung (2009) juga menyatakan dipercaya secara luas bahwa administrator pajak dan wajib pajak yang tumbuh dalam ketidakpuasan dengan keadilan sistem pajak merupakan penyebab utama meningkatnya ketidakpatuhan pajak. Undang-Un- 
dang Perpajakan di Indonesia beserta implementasinya sudah diberlakukan cukup adil dan sama untuk semua wajib pajak tanpa ada perlakuan yang berbeda pada berbagai dimensi. Usaha yang dilakukan adalah sosialisasi kepada seluruh wajib pajak pada berbagai lapisan masyarakat bahwa setiap warga negara mempunyai hak dan kewajiban perpajakan yang sama dan diperlakukan secara adil.

9. Persepsi Mengenai Pengeluaran Pemerintah (Perception of Government Spending).

Palil (2010) menyatakan secara logika wajib pajak, khususnya yang membayar pajak dalam jumlah yang tinggi akan sensitif dengan apa yang dibelanjakan oleh pemerintah atas uang pajak yang dibayarkannya tersebut. Meskipun ada keterbatasan bukti empirikal, namun logis jika diasumsikan bahwa wajib pajak akan cenderung menghindarkan membayar pajak, bila dia merasa bahwa pemerintah membelanjakan uang pajaknya secara tidak bijaksana. Dalam hal ini usaha yang dapat dilakukan adalah agar anggaran pemerintah sebagian besar dibelanjakan untuk programprogram yang dapat dirasakan oleh semua lapisan masyarakat secara merata dan perlu APBN (Anggaran Pendapatan dan Belanja Negara) dan APBD (Anggaran Pendapatan dan Belanja Daerah) beserta realisasinya dipubliksasikan secara transparan kepada masyarakat luas.

10. Peranan dari Otoritas Pajak (The Role of The Tax Authority).

Palil (2010) menyatakan peranan dari otoritas pajak untuk meminimalisasi tax gap dan meningkatkan voluntary compliance jelas sangat penting. Hasseldine and Li (1999) dalam Palil (2010) mengilustrasikan bahwa penempatan pemerintah dan otoritas pajak sebagai bagian utama yang secara kontinu dan efisien mengadministrasikan sistem pajak untuk meminimalisasi tax evasion. Sistem perpajakan di Indonesia dan implementasinya telah dibuat sedemikian rupa, sehingga otoritas pajak sangat berperanan dalam aplikasi sistem perpajakan di lapangan, baik dari segi sumber daya manusia maupun teknologi informasinya, termasuk disediakannya petugas khusus yang melayani sejumlah wajib pajak (account representative). Dilihat dari peranan yang sudah dijalankan otoritas pajak telah menjalankan fungsinya dengan baik. Namun dari segi struktural, kedudukan Direktorat Jenderal Pajak yang berada di bawah Kementrian Keuangan perlu dilakukan reformasi. Seperti kebanyakan negara-negara lain, posisi struktural Direktorat Jenderal Pajak berdiri sendiri dan tidak di bawah Kementrian Keuangan. Peranan lembaga legislatif yaitu DPR (Dewan Perwakilan Rakyat) sudah berjalan dengan baik sesuai fungsinya di bidang penyusunan Undang-Undang Perpajakan dan melakukan pengawasan. Lembaga peradilan di bawah Mahkamah Agung juga telah mendukung proses peradilan pidana perpajakan bekerjasama dengan aparat penegak hukum lainnya dan penyelesaian upaya peninjauan kembali dari wajib pajak atas kasus sengketa pajak.

11. Usia (Age)

Palil (2010) menyebutkan bahwa usia sebagai faktor demografi dite- 
liti oleh banyak peneliti, akan tetapi temuan yang berbeda pada masing-masing studi tidak dapat memberikan kesimpulan yang pasti. Ada hasil penelitian yang menyatakan ada hubungan positif antara usia dengan kepatuhan pajak. Tetapi ada pula yang menemukan hubungan negatif serta ada pula yang memperoleh hasil tidak ada hubungan yang signifikan. Dalam situasi demikian maka tidak ada usia tertentu yang diprioritaskan. Oleh karena itu semua usia akan menjadi perhatian dalam meningkatkan kepatuhan pajak, walaupun usia produktif dan tingkat penghasilan bisa menjadikannya lebih prioritas.

12. Jenis Kelamin (Gender).

Hasil penelitian menunjukkan bahwa wajib pajak dengan jenis kelamin perempuan cenderung lebih patuh pajak dibandingkan dengan pria (Tittle, 1980; Baldry, 1987 dalam Chau and Leung, 2009). Usaha yang dapat dilakukan adalah dengan banyak melakukan sosialisasi/penyuluhan perpajakan ke ibuibu rumah tangga dan kelompok wanita.

13. Pendidikan (Education).

Chan et al. (2000) dalam Chau and Leung (2009) menyatakan pendidikan yang lebih tinggi berhubungan langsung dengan kemungkinan kepatuhan pajak. Penguasaan pengetahuan tentang pajak yang lebih baik akan berhubungan dengan sikap lebih patuh terhadap pajak (Song and Yarbrough, 1978; Eriksen and Fallan, 1996 dalam Chau and Leung, 2009). Usaha yang dapat dilakukan adalah memberikan pengetahuan dan pendidikan mengenai pengetahuan pajak sejak usia dini (tingkat pendidikan sekolah dasar) sampai dengan perguruan tinggi.

14. Sikap (Attitudes).

Banyak penelitian yang mendapatkan hasil yang berbeda mengenai hubungan antara sikap pribadi wajib pajak dengan kepatuhan pajak. Namun Lewis (1982) dalam Mişu (2011) menyatakan jika sikap terhadap pajak buruk, maka tax evasion akan meningkat. Karena masalah sikap berkaitan dengan hal yang bersifat pribadi, maka usaha yang dapat dilakukan adalah melakukan pendekatan pribadi kepada wajib pajak agar patuh memenuhi kewajiban perpajakannya.

15. Kendala/Batasan Keuangan (Financial Constraints).

Palil (2010) menyatakan kendala keuangan pribadi dipercaya mempunyai pengaruh terhadap tax evasion, karena tekanan keuangan yang dihadapi mungkin akan mendorongnya untuk memprioritaskan yang dibayarnya pertama kali untuk kebutuhan hidup dasar (makanan, pakaian, rumah dan sebagainya) atau kebutuhan keuangan yang mendesak sekali (seperti ancaman tindakan dari pemberi pinjaman dan sebagainya) dari pada membayar utang pajak. Mohani and Sheehan (2004) dalam Palil (2010) menyatakan orang yang menghadapi masalah keuangan pribadi lebih mungkin untuk tidak patuh membayar pajak dibandingkan dengan orang yang mempunyai sedikit tekanan keuangan. Dalam hal ini untuk membantu wajib pajak yang kesulitan keuangan, cara mengangsur pembayaran pajak menjadi satu solusi agar wajib pajak tersebut tetap patuh memba- 
yar pajak. Undang-Undang Perpajakan di Indonesia sudah memungkinkan wajib pajak untuk mengangsur pembayaran pajak.

16. Budaya (Culture).

Menurut Chau and Leung (2009) budaya dipertimbangkan sebagai faktor lingkungan yang sangat kuat mempengaruhi kepatuhan pajak. Chan et al. (2000) dalam Chau and Leung (2009) menyatakan dimensi budaya yang mempengaruhi kepatuhan pajak adalah kolektivisme dan individualisme. Usaha yang dapat dilakukan adalah menanamkan budaya patuh membayar pajak pada berbagai kelompok masyarakat, organisasi, lembaga pemerintah dan non pemerintah.

17. Etika dan Norma Sosial (Ethics and Social Norms).

Chau and Leung (2009) menyatatakan norma sosial dan nilai etika yang berbeda akan menciptakan insentif yang berbeda terhadap kepatuhan pajak. Dalam faktanya, nilai etika dipengaruhi norma sosial yang mengkin melarang wajib pajak terlibat dalam tax evasion (Blanthorne and Kaplan, 2008 dalam Chau and Leung, 2009). Usaha yang dapat dilakukan berkaitan dengan ini adalah menanamkan etika untuk membayar pajak dalam kehidupan sosial kemasyarakatan.

18. Pengaruh dari Sesama Rekan atau Kelompok (Peer Influence/Referent Group).

Pengaruh dari sesama rekan atau kelompok ini dapat dari keluarga atau teman. Palil (2010) menyatakan keputusan untuk menghindari pajak atau tidak kadang-kadang dipengaruhi oleh anggota keluarga atau teman. Clotfelter (1983) dalam Palil (2010) juga mengklaim bahwa referensi kelompok memainkan peranan yang signifikan dalam penghindaran pajak, meskipun tidak ada diskusi yang jelas mengenai mana yang lebih kuat pengaruhnya antara teman atau keluarga. Dalam hal ini usaha yang dapat dilakukan adalah meminta wajib pajak untuk mengedukasi dan mempengaruhi teman atau keluarganya agar menjadi wajib pajak yang patuh dengan memanfaatkan faktor kedekatan keluarga atau teman.

\section{KESIMPULAN}

1. Masalah kepatuhan pajak merupakan masalah sentral bagi semua negara di dunia dalam memaksimalkan pendapatannya dari sektor pajak, khususnya pada negara-negara yang menerapkan sistem self assessment dalam sistem pemungutan pajaknya.

2. Banyak faktor yang mempengaruhi kepatuhan dari wajib pajak yang umumnya sangat kompleks dan dapat dibedakan atas faktor-faktor ekonomi dan non ekonomi.

3. Faktor-faktor ekonomi berpengaruh dalam menentukan tingkat kepatuhan wajib pajak, karena wajib pajak selalu berpikir rasional dan ekonomis dalam segala tindakannya termasuk dalam memenuhi kewajibannya membayar pajak, di mana wajib pajak akan selalu membandingkan antara keuntungan dan kerugian yang diperoleh bila wajib pajak tersebut patuh membayar pajak dan jika tidak patuh membayar pajak.

4. Faktor-faktor non ekonomi berpengaruh dalam menentukan tingkat kepatuhan wajib pajak, karena wajib pajak (wajib pajak orang pri- 
badi) atau pribadi pengurusnya (wajib pajak badan) adalah mahluk sosial yang tidak hidup sendiri dalam ruang hampa, tetapi hidup dalam suatu lingkungan masyarakat yang tidak bisa lepas dari pengaruh interaksi sosial dengan lingkungannya.

5. Faktor-faktor ekonomi yang mempengaruhi kepatuhan pajak dapat terdiri dari: tarif pajak (tax rate), pemeriksaan pajak (tax audit), tingkat penghasilan aktual (level of actual income), sumber penghasilan (income source), denda (fine), hukuman (penalty), kemungkinan untuk diperiksa (audit probabilities) dan manfaat pajak (tax benefits).

6. Faktor-faktor non ekonomi yang mempengaruhi kepatuhan pajak dapat dibedakan menjadi faktorfaktor yang berhubungan dengan pengambil kebijakan, faktor-faktor yang berhubungan dengan wajib pajak dan faktor-faktor sosial.

7. Faktor-faktor berhubungan dengan pengambil kebijakan yang mempengaruhi kepatuhan pajak dapat terdiri dari: kompleksitas sistem perpajakan (complexity of the tax system), kesamaan dan keadilan (equity and fairness), persepsi mengenai pengeluaran pemerintah (perception of government spending) dan peranan dari otoritas pajak (the role of the tax authority).

8. Faktor-faktor berhubungan dengan wajib pajak yang mempengaruhi kepatuhan pajak dapat terdiri dari: usia (age), jenis kelamin (gender), pendidikan (education), kendala/ batasan keuangan (financial constraints) dan sikap/perilaku (attitudes).
9. Faktor-faktor sosial yang mempengaruhi kepatuhan pajak dapat terdiri dari: budaya (culture), pengaruh dari rekan atau kelompok (peer influence/referent groups) dan norma sosial.

10. Hasil-hasil penelitian menunjukkan bahwa pengaruh dari banyak faktor, baik ekonomi maupun non ekonomi terhadap kepatuhan pajak sering tidak konsisten antara beberapa peneliti dengan beberapa peneliti lainnya. Beberapa menyatakan ada pengaruh positif, beberapa menyatakan ada pengaruh negatif, tetapi ada beberapa pula yang menyatakan tidak ada pengaruh yang signifikan.

11. Dibandingkan dengan negara-negara lain di dunia dan di kawasan Asia Tenggara tingkat kepatuhan wajib pajak di Indonesia masih rendah.

\section{SARAN}

1. Karena tingkat kepatuhan wajib pajak di Indonesia masih rendah, maka perlu dilakukan berbagai usaha secara berkesinambungan oleh pemerintah untuk meningkatkan kepatuhan wajib pajak, baik berupa usaha preventif maupun represif.

2. Semua usaha yang dilakukan untuk meningkatkan kepatuhan wajib pajak hendaknya digali dengan mempertimbangkan faktor-faktor yang diperkirakan mempengaruhi kepatuhan wajib pajak, baik faktor-faktor ekonomi maupun non ekonomi.

3. Beberapa usaha yang dapat dilakukan untuk meningkatkan kepatuhan wajib pajak di Indonesia antara lain: (i) menurunkan tarif Pajak Penghasilan wajib pajak badan dari $25 \%$ menjadi 20\%, dan tarif Pajak 
Penghasilan orang pribadi dari tarif progresif $5 \%, 15 \%, 25 \%$ dan $30 \%$ menjadi $5 \%, 15 \%$ dan $25 \%$ dengan perubahan pada lapisan penghasilan kena pajak dari 4 lapisan menjadi 3 lapisan saja; (ii) meningkatkan tindakan pemeriksaan baik dari segi kuantitas maupun kualitas dan pemberian perlakuan khusus untuk wajib pajak patuh secara suka rela (voluntary tax compliance), (iii) meningkatkan kompetensi dan profesionalitas pemeriksa pajak dengan tetap mendahulukan pendekatan perdata dari pada pidana; (iv) memberikan prioritas pengawasan yang lebih ketat terhadap wajib pajak dengan penghasilan tinggi dan wajib pajak yang memperoleh penghasilan dari bekerja sendiri; (v) memperluas objek dari pemotongan/pemungutan witholding tax; (vi) meminimumkan adanya perlakuan yang berbeda terhadap wajib pajak, termasuk mengurangi berbagai insentif pajak; (vii) menyederhanakan tarif Pajak Penghasilan bersifat final dan penghapusan aturan kewajiban memungut Pajak Pertambahan Nilai untuk bendaharawan pemerintah dan badan-badan tertentu; (viii) Sosialisasi dan edukasi mengenai implementasi hak dan kewajiban wajib pajak yang sama dan adil pada seluruh lapisan masyarakat, baik perorangan maupun kelompok, termasuk wanita dan anak-anak melalui forum yang bersifat formal maupun informal serta melalui bangku sekolah dari pendidikan dasar sampai pendidikan tinggi; (ix) Memprioritaskan anggaran pemerintah (APBN dan APBD) untuk belanja programprogram yang hasilnya dapat dirasakan langsung oleh seluruh lapisan masyarakat dengan menggunakan sistem penganggaran, pembelanjaan, monitoring dan evaluasi/audit yang transparan, akuntabel dan terhindar dari tindakan penyalahgunaan (korupsi); (x) restrukturisasi organisasi Direktorat Jenderal Pajak menjadi lembaga yang berdiri sendiri, langsung di bawah presiden dan bukan di bawah Kementrian Keuangan seperti saat ini; (xi) melakukan pendekatan secara pribadi yang lebih intens kepada wajib pajak melalui account representative agar mereka konsisten tetap patuh dan dapat mempengaruhi rekan atau keluarganya untuk menjadi patuh juga; (xii) menanamkan budaya dan etika patuh membayar pajak (malu tidak patuh membayar pajak) kepada berbagai kelompok masyarakat, organisasi, lembaga pemerintah maupun non pemerintah.

\section{DAFTAR KEPUSTAKAAN}

Allingham, Michael G. and Agnar Sandmo, 1972, Income Tax Evasion: A Theoretical Analysis, Journal of Public Economics, No. 1, page 323-338.

Andreoni, James, Brian Erard and Jonathan Feinstein, 1998, Tax Compliance, Journal of Economic Literature, Vol. XXXVI, page 818860 .

Belkaoui, Ahmed Riahi, 2004, Relationship Between Tax Compliance Internationally and Selected Determinants of Tax Morale, Journal of International Accounting, Auditing and Taxation, page 135-143. 
Chau, Gerald and Patrick Leung, 2009, A Critical Review of Fischer Tax Compliance Model: A Research Synthesis, Journal of Accounting and Taxation, Vol. 1, No. 2, page 34-40.

Devos, Ken, 2014, Factors Influencing Individual Taxpayer Compliance Behaviour, Springer.

Fukofuka, Paula, 2013, The Contextual Framework of Corporate Income Tax Evasion, Journal of Accounting and Taxation, Vol. 5, No. 2, page 27-37.

Gangl, Katharina, Eva Hofmann and Erich Kirchler, 2015, Tax Authorities' Interaction With Taxpayers: A Conception of Compliance in Social Dilemmas by Power and Trust, New Ideas in Psychology, No. 37, page 13-23.

Hyun, Jin Kwon, 2005, Tax Compliance in Korea and Japan: Why are They Different?, Policy Research Institute, Ministry of Finance, Japan, page 1-15.

James, Simon and Clinton Alley, 2002, Tax Compliance, Self-Assessment and Tax Administration, Journal of Finance and Management in Public Services, Vol. 2, No. 2, page 27-42.

Jayawardane, Damayanthi, 2015, Psychological Factors Affect Tax Compliance: A Review Paper, International Journal of Arts and Commerce, Vol. 4, No. 6.

Jimenez, Peggy and Govind S. Iyer, 2016, Tax Compliance in A Social Setting: The Influence of Social Norms, Trust in Government, and
Perceived Fairness on Taxpayer Compliance, Advances in Accounting, Incorporating Advances in International Accounting, No. 34, page 17-26.

Kirchler, Erich, Stephan Muehlbacher, Barbara Kastlunger and Ingrid Wahl, 2007, Why pay Taxes? A Review of Tax Compliance Decisions, Working Paper 07-30, International Studies Program.

Marandu, Edward E., Christian J. Mbekomize and Alexander $\mathrm{N}$. Ifezue, 2015, Determinants of Tax Compliance: A Review of Factors and Conceptualizations, International Journal of Economics and Finance, Vol. 7, No. 9, page 207218.

McBarnet, Doreen, 2001, When Compliance is not The Solution But The Problem: From Changes in Law to Changes in Attitude, Working Paper No. 18, The Australian National University, Australian Taxation Office.

Mișu, Nicoleta Bărbuţă, 2011, A Review of Factors for Tax Compliance, Economics and Applied Informatics Years XVII, No. 1, Annals of Dunarea de Jos, University of Galati, page 69-76.

Palil, Mohd Rizal, 2010, Tax Knowledge and Tax Compliance Determinants in Self Assessment System in Malaysia, Thesis, Department of Accounting and Finance Birmingham Business School, The University of Birmingham.

Palil, Mohd Rizal and Ahmad Fariq Mustapha, 2011, The Evolution and Concept of Tax Compliance in Asia 
and Europe, Australian Journal of Basic and Applied Sciences, Vol. 5, No. 11, page 557-563.

Pomerleau, Kyle and Emily Potosky, 2016, Corporate Income Tax Rates Around The World, Tax Foundation Fiscal Fact, No. 525, page 1-8.

Undang-Undang Republik Indonesia Nomor 6 Tahun 1983 tentang Ketentuan Umum dan Tata Cara Perpajakan yang telah diubah beberapa kali, terakhir dengan UndangUndang Nomor 16 Tahun 2009.
Undang-Undang Republik Indonesia Nomor 7 Tahun 1983 tentang Pajak Penghasilan yang telah diubah beberapa kali, terakhir dengan Undang-Undang Nomor 36 Tahun 2008 .

Undang-Undang Nomor 19 Tahun 1997 tentang Penagihan Pajak dengan Surat Paksa yang telah diubah dengan Undang-Undang Nomor 19 Tahun 2000. 